\title{
Teenagers' motorcycle gang community aggression from the Personal Fable and risk-taking behavior perspective
}

This article was published in the following Dove Press journal:

Psychology Research and Behavior Management

\author{
A Nur Aulia Saudi' \\ Nurul Hartini' \\ Bahar Bahar ${ }^{2}$ \\ 'Faculty of Psychology, Universitas \\ Airlangga, Surabaya, Indonesia; ${ }^{2}$ Faculty \\ of Economic and Social Science, \\ English Literature Department, \\ Universitas Fajar, Makassar, Indonesia
}

Introduction: The number of criminal acts committed by teenagers who are members of the motorcycle gang community in the Makassar City of Indonesia continues to increase at an alarming rate. Among the antisocial behaviors of teenagers in motorcycle gangs which might lead to criminal behavior is aggression. This study aimed to examine the aggression of teenagers in the motorcycle gang community in one area of Makassar City from the Personal Fable (dimensions of omnipotence, uniqueness and invulnerability) and risk-taking behavior perspective.

Methods: Data were obtained through survey research involving 110 participants. Data collection tools included Personal Fable questionnaires, risk-taking behavior questionnaires, and aggression questionnaires. Multiple linear regression analysis resulted in a $\mathrm{R}$ square value of $0.516(p=0.00)$.

Results: The results show that the Personal Fable, especially the dimensions of invulnerability, and risk-taking behavior had remarkable contributions in the adolescent aggression score, while the omnipotence and uniqueness dimensions of the Personal Fable were not found as significant predictors.

Conclusion: The results implied that perceived invulnerability and tendency to engage in risky behavior could markedly predict juvenile aggression. Social intervention aimed at adolescents' talent and potential development is necessary to channel the destructive tendency of motorcycle gang members into a more favorable hobby.

Keywords: Personal Fable, risk-taking behavior, teen aggression, motorcycle gang

\section{Introduction}

Indonesia is encouraging the achievement of the Indonesia Gold Program in 2045 with several programs to improve the quality of human resources through education and health. However, the number of criminal acts is increasing at an alarming pace. One of the crimes which numbers indicate an increase is the act of aggression committed by a group of motorcycle gangs, where the perpetrator and the victim are members of the community itself. The phenomenon of aggression performed by the motorcycle gang has become a trending topic that disturbs the Indonesian people today, with no exception of the people of Makassar City. This is because the actions of motorcycle gangs increasingly have a negative impact on society by disturbing public order, increasing the acts of robbery and mugging, and increasing even the act of murder. Most concerning is that members of the motorcycle gang community are not only adults, but also are teenagers or minors. ${ }^{1}$ White ${ }^{2}$ suggests that motorcycle gangs that teenagers initially regard as a hobby continue to grow into wild and uncontrolled activity.
Correspondence: Nurul Hartini Faculty of Psychology, Universitas Airlangga Campus B, Jl. Airlangga 4-6, Surabaya 60586, Indonesia Email nurul.hartini@psikologi.unair.ac.id 
Based on Polrestabes Makassar data, there were 442 cases of motorcycle gangs in 2015. This number increased significantly from 2014, which accounted to only 254 cases. According to the hundreds of reports of community complaints spread across Makassar City, the police completed 194 cases, naming hundreds of suspects, with most of the perpetrators being minors and almost $70 \%$ teenagers. During teenage, individuals tend to imitate behaviors that are thought to be self-proclaiming. ${ }^{3}$ Teenagers are individuals who are in the stage of identity searching. Teenagers' need for self-existence causes them to continue to try something that is considered new, happy, and unique, without realizing that this behavior leads to acts of aggression. ${ }^{4}$

Pardiningsih ${ }^{5}$ suggests that the emergence of aggressive driving behavior is a form of a dysfunctional pattern of social behavior that can disrupt public security. The examples of aggressive driving behavior are trailing, beeping, and performing rough movements or acts of aggression. Magar et $\mathrm{al}^{6}$ suggest that aggressive driving behavior is included in risktaking behavior, i.e., negative and maladaptive risk action.

Teenagers are at the stage of searching for new sensations and experiences, and for this purpose teenagers have a willingness to take risks. Teenagers will tend to try new things that are challenging, bringing creativity and perspective that are different from others in general. ${ }^{7}$ The search for this sensation can lead to negative behavior when teenagers can only find challenges in ways that violate the norm of society, actualize themselves in a less praiseworthy attitude, and often engage in an aggressive or high-risk behavior such as racing on the road without wearing a helmet. ${ }^{8}$

Barry et $\mathrm{al}^{9}$ suggest that the Personal Fable is a part of teenage egocentrism in which teenagers believe that it is impossible for them to make the same mistakes that other people do. Vartanian ${ }^{10}$ suggests that the Personal Fable is part of the teenage egocentrism associated with unique feelings, by possessing great special characteristics and being unaware of other viewpoints and facts. In addition, adolescents tend to show that they are immune and believe never to suffer from a bad experience, such as a deadly driving accident. This tends to make careless behavior, such as wild races, more appealing to teenagers, thus breaking the norm of society.

Regarding the Personal Fable, there are three dimensions: omnipotence, invulnerability, and uniqueness. Santrock ${ }^{11}$ suggests that the Personal Fable dimension of omnipotence is more concerned with the internalization of behavior and isolation. It is a manifestation of internal behavior that can produce strong self-beliefs, while the negative side is associated with depression and suicidal ideation. The dimension of omnipotence is more stressful for teenagers. Greene et $\mathrm{al}^{24}$ suggest that the Personal Fable of the invulnerability dimension is a prediction of teenagers' actions toward risk-taking behavior. ${ }^{12}$ Invulnerability correlates with externalization behavior and the willingness of risk taking; the negative side of them is leading to acts of aggression, promiscuity, criminal activity, dangerous driving, and drug use. Uniqueness is a strong confidence for them to always get a new experience unique to themselves that others will not be able to feel. The Personal Fable is an important component in explaining risk-taking behavior.

Ritcher ${ }^{13}$ stated that there is a correlation between egocentrism (the Personal Fable) and risk-taking behavior. Teenagers are egocentric (the Personal Fable); they have high risk-taking behavior because teenagers have self-confidence that make them feel great and are courageous in making decisions, without thinking about long-term risks or the consequences of the actions performed. Albert et a $\mathrm{l}^{14}$ stated risk-taking behavior is the implementation of an individual's choice of action that can lead to negative consequences and can result in more than one unwanted or even harmful outcome.

\section{Method}

\section{Participants}

Makassar is one of the cities in Indonesia with a high number of motorcycle gangs; therefore, the researchers set Makassar as a research location. Local police reported hundreds of public complaints of criminal cases caused by motorcycle gangs. There were 110 male teenage participants aged 13-16 years in the study. None of them held a driver's license, yet they were all members of one of the Makassar motorcycle gang communities.

\section{Data collection}

Data collection techniques involved the use of questionnaires. The Personal Fable scale developed by Lapsley consists of three dimensions: $:^{15}$ 1) omnipotence, that an individual's confidence is more powerful than others, 2) uniqueness, the belief that he or she always gets a new experience unique to himself or herself and others will not be able to feel it, and 3) invulnerability, the individual beliefs that he or she will always avoid the problem unlike others. Risk-taking behavior scale, developed by researchers with reference to the theory of risk-taking behavior by Gullone et al, ${ }^{16}$ is divided into four aspects: thrill-seeking behavior, reckless behavior, rebellious behavior, and antisocial behavior. The scale of aggression using the concept by Buss and Perry consists of 
four aspects: physical aggression, verbal aggression, anger, and hostility. ${ }^{17}$ Physical aggression and verbal aggression represent motor components in aggressiveness, while anger and hostility represent the affective and cognitive components of aggression.

The Personal Fable scale has reliability described in three dimensions: omnipotence has Cronbach's alpha of 0.732 , uniqueness dimension has Cronbach's alpha equal to 0.626 , and the dimension of invulnerability has Cronbach's alpha of 0.795 . The scale of risk-taking behavior has reliability with Cronbach's alpha of 0.762 , while the scale of aggression has reliability with Cronbach's alpha of 0.879 .

Prior to the data collection process, a research permit was obtained from the police, the school, and the motorcycle gang leader and its members.

\section{Data analysis}

The data analysis technique used was the multiple linear regression analysis with SPSS 20.0 for Windows. The analysis was used to test the hypothesis about the influence of Personal Fable variables (omnipotence, uniqueness, and invulnerability) and risk-taking behavior toward adolescent aggression in Makassar motorcycle gang community.

\section{Research result}

\section{F-test results}

Table 1 shows that the ANOVA test resulted in significant F-ratio value $(p<0.001)$, meaning that the overall regression model in this research predicted markedly well aggression.

\section{Model parameters results}

Table 2 shows the model parameters. As shown, omnipotence $(\beta=0.166, p=0.869)$ and uniqueness $(\beta=-0.91, p=0.365)$ were not found to be significant predictors for aggression score. On the other hand, invulnerability was the only dimension of the Personal Fable that notably predicted aggression $(\beta=9.487$, $p<0.001)$. Additionally, risk-taking behavior was also proved as a significant predictor of juvenile aggression in motorcycle gang communities $(\beta=2.891, p<0.01)$.

Table I F-test result

\begin{tabular}{llllll}
\hline ANOVA $^{\mathrm{a}}$ & & & & & \\
\hline Model & $\begin{array}{l}\text { Sum of } \\
\text { squares }\end{array}$ & Df & $\begin{array}{l}\text { Mean } \\
\text { square }\end{array}$ & F & Significance \\
\hline I Regression & 7972.550 & 4 & 1993.138 & 27,938 & $0.000^{\mathrm{b}}$ \\
Residual & 7490.722 & 105 & 71.340 & & \\
Total & 15463.273 & 109 & & & \\
\hline
\end{tabular}

Notes: ${ }^{a}$ Dependent variable: aggression. ${ }^{b}$ Predictors: (constant), risk-taking behavior, omnipotence, invulnerability, uniqueness.
Table 2 Model parameters

\begin{tabular}{|c|c|c|c|c|c|c|}
\hline \multirow{2}{*}{\multicolumn{2}{|c|}{ Model $^{a}$}} & \multicolumn{2}{|c|}{$\begin{array}{l}\text { Unstandardized } \\
\text { coefficients }\end{array}$} & \multirow{2}{*}{$\begin{array}{l}\text { Standardized } \\
\text { coefficients } \\
\beta\end{array}$} & \multirow[t]{2}{*}{$\mathbf{T}$} & \multirow[t]{2}{*}{ Sig. } \\
\hline & & B & $\begin{array}{l}\text { Standard } \\
\text { error }\end{array}$ & & & \\
\hline \multirow[t]{5}{*}{1} & (Constant) & 26.806 & 10.700 & & 2.505 & 0.014 \\
\hline & Omnipotence & 0.019 & 0.117 & 0.012 & 0.166 & 0.869 \\
\hline & Uniqueness & -0.149 & 0.164 & -0.069 & -0.910 & 0.365 \\
\hline & Invulnerability & 1.273 & 0.134 & 0.651 & 9.487 & 0.000 \\
\hline & $\begin{array}{l}\text { Risk-taking } \\
\text { behavior }\end{array}$ & 0.182 & 0.063 & 0.205 & 2.891 & 0.005 \\
\hline
\end{tabular}

Note: a Dependent variable: aggression.

Table 3 Multiple regression analysis

\begin{tabular}{|c|c|c|c|c|c|}
\hline Model & $\mathbf{R}$ & R square & $\begin{array}{l}\text { Adjusted } \\
\text { R square }\end{array}$ & $\begin{array}{l}\text { Standard } \\
\text { error of the } \\
\text { estimate }\end{array}$ & $\begin{array}{l}\text { Durbin- } \\
\text { Watson }\end{array}$ \\
\hline $\mathrm{I}^{\mathrm{b}}$ & $0.718^{a}$ & 0.516 & 0.497 & 8.446 & 2.359 \\
\hline
\end{tabular}
uniqueness. 'Dependent variable: aggression.

Table 3 shows the magnitude of R-value as 0.718 , whilst the column $\mathrm{R}$ square $\left(\mathrm{R}^{2}\right)$ has a coefficient of determination of 0.516 . Therefore, it can be concluded that the predictors in the regression model (i.e., the Personal Fable [omnipotence, uniqueness, and invulnerability] and risk-taking behavior) could account for $51.6 \%$ of the variation in the juvenile aggression score, while the rest (48.4\%) is explained by other variables outside research.

\section{Declaration}

All participants and their parents or legal guardians gave their written informed consent before participating in this study. The Board of Ethic, Faculty of Psychology, Universitas Airlangga approved this study.

\section{Discussion}

The result of this study proves that the Personal Fable, especially the dimension of invulnerability, and risk-taking behavior significantly predict teenager aggression that is incorporated in the gang community of Makassar City Indonesia.

Baron and Byrne ${ }^{18}$ argue that aggression is the behavior of individuals who have a series of behaviors that have a purpose to harm others. Bryant and Smith ${ }^{19}$ suggest that every human being has an aggressive behavior and that it cannot be avoided. The examples of external aggressive behaviors directed to self-defense are brawling, abusing others, harassing others, and violating rules. The examples of internal aggressive behavior are depression, self-harm, and suicide. Aggression behavior of motorcycle gangs, according 
to Raahman, ${ }^{20}$ is the action of a group of motorcycle gangs that can harm others by doing various forms of crime such as property destruction, deliberately violating, and opposing adult authority along with conventional morality.

The results are consistent with Aalsma et al; ${ }^{21}$ they suggest that the Personal Fable, particularly the dimension of invulnerability, describes a cognitive process that explains immunity to the environment, confidence to always get a new unique experience for himself or herself that others will not be able to feel, and even the individual has the belief that he or she will always avoid the problems unlike others. Elkind et $\mathrm{al}^{22}$ suggest that the Personal Fable raises the element of immunity to the individual so that he or she is not afraid of the consequences, even if it will have a negative impact on himself or herself. Teenagers who are members of the motorcycle gang community in Makassar City drive with confidence, emotionally perceive themselves as great individuals, show behaviors of forcing, and give negative risks to themselves and other vehicle riders. Such self-perception can lead teenagers to do reckless things because they deem themselves as strong and invulnerable against any possible danger while riding motorcycle. Invulnerability dimension correlate with externalization behavior, risk-taking, and aggression, including dangerous driving.

Regarding the Personal Fable variables, dimensions omnipotence and uniqueness did not notably predict teenager aggression in motorcycle gang communities. This finding is in accordance with that proposed by Santrock ${ }^{11}$ that the Personal Fable dimensions of omnipotence and uniqueness are more related to the internalization behavior and isolation. This is a manifestation of internal behavior that can lead to depression and suicidal ideation. The dimensions of omnipotence and uniqueness are not correlated with the aggression behavior of motorcycle gang members because aggression behavior is an external manifestation.

Aalsma et $\mathrm{al}^{21}$ suggest that the Personal Fable, especially the omnipotence dimension, does not always have a negative influence, but also has a positive effect. Teenagers will consider themselves valuable when they feel powerful compared to others and always have a strong desire to move forward. Teenagers will show inner omnipotence and what is felt by showing an adaptive psychological picture. A positive Personal Fable will lead to achievement, hobbies, talent, and interest.

The uniqueness dimension of the Personal Fable was not found as an important predictor of teen aggression in motorcycle gang communities. Some research indeed suggested that personal uniqueness might not be adaptive and healthy. ${ }^{23}$ Healthy uniqueness will make individuals more productive and creative. Adolescence is a period marked by an increase in creativity and originality that often conjures up unique and original thoughts, unlike others. Aalsma et al ${ }^{21}$ argued that the Personal Fable, especially the dimension of uniqueness, is a feeling that teenagers always want to experience as something new and different from others.

Further, risk-taking behavior was proved as a significant predictor of teenager aggression in the motorcycle gang community. Magar et $\mathrm{al}^{6}$ research focuses on risk-taking behaviors manifested in negative maladaptive actions, such as aggression in driving. Risk-taking behavior might be deemed as prosocial behavior for adolescents. Among the goals that adolescents join in the motorcycle gang is to provide social support from their peer group. They provide support so that their community get a chance to have new, challenging, and risky experience.

Aggression tendency among motorcycle gang communities in Makassar City in Indonesia is built upon adolescents' cognitive process, which drives them to get new and unique experience for themselves and a belief that they will be able to avoid all kinds of danger and risks such as traffic accident while riding their motorcycle. Additionally, adolescents' inclination to seek sensation amidst the process of identity development is manifested though the drive to gain new and more challenging experience. Therefore, adolescents whose hobby is riding motorcycle can be directed to join a legal motorcycle racing competition so that the strong drive to develop identity and self-actualize can be channeled in a positive manner.

\section{Study limitation}

Some of the research limitations, such as data collection tools in the form of questionnaires, are predicted to be less able to reveal the contents of a concept or variable measured in depth. This research could not explain in detail about the internal motivation of teenagers to join a community of motorcycle gangs who are at risk of negative behavior. In addition, there is a tendency to choose an alternative answer with a positive assessment, as expected by the community, so that the data do not match the self-image and self-experience with the actual condition. The limited number of samples is due to the difficulty of finding participants that fit the characteristics because not all members of the community motorcycle gangs are willing to be research participants.

\section{Conclusion}

The omnipotence and uniqueness variables of the Personal Fable do not significantly predict aggression, while 
invulnerability and risk-taking behavior markedly predict teen aggression of motorcycle gang communities in Makassar City. Aggression behavior is formed and evolved through a series of processes, where unconsciously the role of culture and the environment of residence becomes a social medium in its formation. Given that some motorcycle gang members are teenagers who are dropping out of school, it is necessary to design a social intervention for talent development and adolescent potential, thus providing an opportunity for adolescents to work in a good and healthy way. The government and the community are expected to provide facilities and infrastructure in channeling and expressing this hobby of teenagers through the automotive field by conducting official motorcycle racing, tightening the security, and doing raids on motorcycle gangs.

\section{Disclosure}

The authors report no conflicts of interest in this work.

\section{References}

1. Sahiri. Criminological Review Against the Violent Behavior of Motorcycle Gang Members in the City of Makassar [Essay]. Makassar: Hasanuddin University; 2012. Available from: http://repository.unhas. ac.id/handle/123456789/3658. Accessed July 10, 2018. Indonesian.

2. White R. Geng Remaja Fenomena dan Tragedi Geng Remaja di Dunia. Yogyakarta: gala Ilmu Semesta [The Phenomenon of Juvenile Gangs and Tragedy of Teenage Gangs in the World]. 2008. Available from: https://www.berdikaribook.red/geng-remaja-fenomena-dan-tragedigeng-remaja-dunia.html. Accessed July 10, 2018. Indonesian.

3. Hartini N. Remaja Nangroe Aceh Darussalam Pasca Tsunami [Adolescents of Nangroe Aceh Darussalam After Tsunami]. Masyarakat Kebudayaan dan Politik. 2011;24(1):45-51. Available from: http:// journal.unair.ac.id/MKP@remaja-nangroe-aceh-darussalam-pascatsunami-article-4058-media-15-category-8.html. Accessed July 10, 2018.

4. Wulaningsih R, Hartini N. Hubungan antara Persepsi Pola Asuh Orangtua dan Kontrol Diri Remaja terhadap Perilaku Merokok di Pondok Pesantren [Relationship between Perceived Parenting and Adolescent Self-Control with Smoking in Islamic Boarding School]. Jurnal Psikologi Klinis dan Kesehatan Mental. 2015;4(2):119-126. Indonesian.

5. Pardiningsih N. Relationship between Risk Taking Behavior with Aggressive Driving. [Thesis]. Yogyakarta: Universitas Islam Indonesia; 2008.

6. Magar ECE, Phillips LH, Hosie JA. Self-regulation and risk-taking. Personal Individ Differ. 2008;45(2):153-159.
7. Astuti K, Walgito PPDB. Model Kognitif Sosial Perilaku Merokok Pada Remaja [Social Cognitive Model of Adolescent Smoking Behavior]. [Doctoral dissertation]. Yogyakarta: Universitas Gadjah Mada; 2010. Indonesian.

8. Yulandari S. Hubungan antara Egosentrisme dan Kecenderungan Mencari Sensasi dengan Perilaku Agresi pada Remaja [Relationship between Egocentrism and Sensation-Seeking Tendency with Aggression in Adolescents]. [Doctoral dissertation]. Universitas Muhammadiyah Surakarta; 2008. Available from: http://eprints.ums.ac.id/837/. Accessed July 10, 2018. Indonesian.

9. Barry CT, Pickard JD, Ansel LL. The associations of adolescent invulnerability and narcissism with problem behaviors. $J$ Personal Individ Differ. 2009;47:577-582.

10. Vartanian LR. Revisiting the imaginary audience and personal fable constructs of adolescent egocentrism: a conceptual review. Adolescence. 2000;35(140)639-661.

11. Santrock JW. Life-Span Development: Edition V. (Translator: Chusairi A, Damanik J; Editor. Sinaga H, Sumiharti Y). Jakarta: Erlangga; 2002.

12. Papalia D, Olds S, Feldman R. Human Development. 8th ed. New York: McGraw-Hill; 2001.

13. Ritcher M. Risk Behavior in Adolescence, Patterns, Determinants, and Consequences. Germany: Springer Fachmedien; 2010.

14. Albert A, Elkind D, Ginsberg S. The personal fable and risk-taking in early adolescence. $J$ Youth Adolesc. 2007;36:71-76.

15. Galanaki PE. The imaginary audience and the personal fable: a test of Elkind's theory of adolescent egocentrism. JPsychol. 2012;3(6):457-466.

16. Gullone E, Moore S, Moss S, Boyd C. The adolescent risk-taking questionnaire: development and psychometric evaluation. J Adolesc Res. 2000;15(2):231-250.

17. García-León A, Reyes GA, Vila J, Pérez N, Robles H, Ramos MM. The Aggression Questionnaire: a validation study in student samples. Span J Psychol. 2002;5(1):45-53.

18. Baron RA, Byrne D. Social Psychology. Boston: Allyn \& Bacon; 2004.

19. Bryant FB, Smith BD. Refining the architecture of aggression: a measurement model for the Buss-Perry Aggression Questionnaire. J Res Personal. 2001;35:138-167.

20. Raahman A. Penerapan sanksi hukum terhadap kejahatan geng motor yang Dilakukan anak di bawah umur [Legal sanction implementation toward motorcycle gang crime by underaged children]. Al-Daulah: Jurnal Hukum Pidana dan Ketatanegaraan. 2016;5(1):174-187. Indonesian.

21. Aalsma MC, Lapsley DK, Flannery DJ. Personal fables, narcissism, and adolescent adjustment. Psychol Sch. 2006;43(4):481-491.

22. Elkind D, Fallon R, Maynard AM, Pisano PA, Schwartz H, MurrayCohen S. Egocentrism across the life cycle: a discussion of Elkind's personal fable and imaginary audience constructs. Paper presented at: the Eastern Psychological Association; 2005; Boston, MA.

23. Banerjee SC, Greene K, Yanovitzky I, Bagdasarov Z, Choi SY, Magsamen-Conrad K. Adolescent egocentrism and indoor tanning: is the relationship direct or mediated? JYouth Stud. 2015;18(3):357-375.

24. Greene K, Krcmar M, Walters LH, Rubin DL, Hale L. Targeting adolescent risk-taking behaviors: the contributions of egocentrism and sensation-seeking. J Adolesc. 2000;23(4):439-461.
Psychology Research and Behavior Management

\section{Publish your work in this journal}

Psychology Research and Behavior Management is an international, peerreviewed, open access journal focusing on the science of psychology and its application in behavior management to develop improved outcomes in the clinical, educational, sports and business arenas. Specific topics covered in the journal include: Neuroscience, memory and decision making; Behavior modification and management; Clinical applications; Business and sports performance management; Social and developmental studies; Animal studies. The manuscript management system is completely online and includes a very quick and fair peer-review system, which is all easy to use. Visit http://www. dovepress.com/testimonials.php to read real quotes from published authors. 